LINGUA, Vol. 16, No. 2, September 2019

p ISSN: 1979 9411; e ISSN: 2442 238X

Http://lingua.soloclcs.org; Email: presslingua@gmail.com

Center of Language and Cultural Studies, Surakarta, Indonesia

Lestari, Aste Nunu Aa; Rusdiawan \& Sudirman. 2019. Kemampuan Guru Melaksanakan

Pembelajaran Bahasa Indonesia Berbasis Kurikulum 2013 di SMPN 1 Pujut Nusa Tenggara Barat. Lingua (2019), 16(2): 207-218. Http://doi.org/10.30957/lingua.v16i2.268.

\title{
Kemampuan Guru Melaksanakan Pembelajaran Bahasa Indonesia Berbasis Kurikulum 2013 di SMPN 1 Pujut, Nusa Tenggara Barat
}

\author{
Aa Nunu Aste Lestari, Rusdiawan \& Sudirman \\ Magister Pendidikan Bahasa Indonesia Universitas Mataram \\ Jalan Majapahit No. 62 Kota Mataram Nusa Tenggara Barat \\ Email: nunulestari93@gmail.com, rusdiawan@live.com, sudirmanmtr@gmail.com
}

\begin{abstract}
In this study, we address two purposes: to see the appropriateness between the lesson plan and comprehensible aspects of the 2013 Curriculum components, and appropriateness between teaching preparation made by teachers and the K13 contents. This study employed qualitative approached applying observation and questionnaire to collect data. Analysis was based upon Miles and Huberman (1994) theories on data collection, data reduction, data display, verification and cioncklusion drawing. Results show that the suitability between completeness of the components lesson plan with Curriculum 2013 is very less appropriate and the percentage suitability between learning process with teacher's lesson plan $54.34 \%$ indicates low appropriateness. Completeness and components of lesson plan are low in seven aspects: indicator formulation, learning objectives, material development, teaching method plan, selection of media and learning resources, plan of teaching stages, and assessment and evaluation process. In addition, the appropriateness of learning process and plan in the lesson plan is perceived in different way dependent in teacher role and context when teaching in the classroom.
\end{abstract}

Keywords: lesson plan, teaching learning process, the 2013 Curriculum

\section{PENDAHULUAN}

Pada dasarnya guru di setiap satuan pendidikan memiliki kewajiban untuk menyusun RPP secara lengkap dan sistematis agar suatu kegiatan belajar mengajar dapat berlangsung dengan baik serta mampu mencapai tujuan yang diharapkan. Selain itu, guru adalah orang yang bertanggungjawab untuk mengembangkan dan melaksanakan kurikulum hingga mengevaluasi ketercapaiannya. Pada Kurikulum 2013 guru tidak lagi dibebani dengan kewajiban membuat silabus seperti pada KTSP. Silabus dan bahan ajar dibuat oleh pemerintah, sedangkan guru hanya menyusun dan mempersiapkan RPP serta media pembelajarannya. Sebelum menyusun sebuah RPP, guru harus mampu menguasai unsur-unsur yang ada di dalam RPP serta memiliki pengetahuan dan pemahaman tentang tagihan yang ada dalam Kurikulum 2013. Hal 
LINGUA, Vol. 16, No. 2, September 2019

p ISSN: 1979 9411; e ISSN: 2442 238X

Http://lingua.soloclcs.org; Email: presslingua@gmail.com

Center of Language and Cultural Studies, Surakarta, Indonesia

Lestari, Aste Nunu Aa; Rusdiawan \& Sudirman. 2019. Kemampuan Guru Melaksanakan

Pembelajaran Bahasa Indonesia Berbasis Kurikulum 2013 di SMPN 1 Pujut Nusa Tenggara Barat.

Lingua (2019), 16(2): 207-218. Http://doi.org/10.30957/lingua.v16i2.268.

tersebut disebabkan tingkat pemahaman yang dimiliki seorang guru mengenai RPP dan kurikulum yang berlaku menentukan kualitas RPP yang dihasilkan.

Pelaksanaan pembelajaran yang dilakukan seorang guru sangat ditentukan dari seberapa besar kualitas perencanaan yang dibuatnya. Melalui perencanaan yang baik guru akan lebih mudah dalam melaksanakan pembelajaran dan siswa akan lebih terbantu dan mudah dalam belajar. Komponen-komponen dalam RPP seperti kompetensi dasar, materi pokok, indikator, pengalaman belajar, alokasi waktu, sumber, langkah-langkah pembelajaran, dan rencana penilaian yang dirumuskan dengan baik dan digambarkan dengan jelas dapat mendorong guru lebih siap melakukan kegiatan pembelajaran. Oleh karena itu, dapat dikatakan merupakan sebuah kewajiban bagi guru untuk mampu membuat RPP yang baik. Hal tersebut disebabkan tanpa perencanaan yang matang, target pembelajaran akan sulit tercapai secara maksimal.

RPP sangat menentukan keberhasilan kegiatan belajar mengajar di kelas. Meskipun demikian, realitasnya masih banyak guru yang belum mampu menyusun RPP dengan baik. Ada beberapa faktornya yang dapat dikemukakan mengapa hal tersebut bisa terjadi, pertama karena tidak memahami hakikat RPP, prinsip penyusunan RPP, serta beranggapan bahwa menyusun RPP itu bukanlah hal penting. Kedua guru malas untuk menyusun RPP. Akibatnya banyak guru menempuh jalan instan seperti copy paste milik teman, download dari internet, atau bahkan membeli RPP yang sudah jadi. Melihat realitas yang ada di kalangan guru saat ini, maka perlu dilakukan penelitian tentang analisis RPP bahasa Indonesia di sekolah untuk mengetaui kemampuan guru dalam mendesain dan menerapkan rencana pelaksanaan pembelajaran.

\section{KAJIAN TEORI}

Kurikulum 2013 merupakan kurikulum berbasisi kompetensi yang merupakan penyempurnaan dari Kurikulum Tingkat Satuan Pendidikan (KTSP). Sebagai sebuah kurikulum yang berbasis kompetensi, elemen pertama yang disempurnakan dalam Kurikulum 2013 adalah rumusan tentang standar kompetensi lulusan yang dirancang untuk mengembangkan kompetensi sikap, pengetahuan, dan keterampilan secara terpadu. Setelah SKL elemen kedua yang disempurnakan adalah standar isi yang berisi rumusan tentang kerangka dasar dan struktur kurikulum yang di dalamnya memuat kompetensi inti dan kompetensi dasar untuk mencapai SKL. Elemen ketiga yang disempurnakan dalam Kurikulum 2013 adalah cara yang digunakan untuk membelajarkan peserta didik untuk menguasai SKL dan standar isi yang dituangkan dalam standar proses. Pada Kurikulum 2013 guru tidak lagi dibebani untuk membuat silabus seperti pada KTSP. Silabus dan bahan ajar dibuat oleh pemerintah, sedangkan guru hanya menyusun dan mempersiapkan RPP serta media pembelajarannya.

Rencana Pelaksanaan Pembelajaran (RPP) merupakan suatu bentuk prosedur dan manajemen pembelajaran untuk mencapai kompetensi dasar yang telah ditetapkan dalam standar isi (standar kurikulum) (dalam Daryanto dan Dwicahyono, 2014:87). Berdasarkan Permendikbud No. 18A tentang Implementasi Kurikulum 2013 dijelaskan bahwa RPP paling sedikit memuat identitas sekolah (sekolah, matapelajaran, Kelas/semester, materi pokok, alokasi waktu), Kompetensi Inti, Kompetensi Dasar dan 
LINGUA, Vol. 16, No. 2, September 2019

p ISSN: 1979 9411; e ISSN: 2442 238X

Http://lingua.soloclcs.org; Email: presslingua@gmail.com

Center of Language and Cultural Studies, Surakarta, Indonesia

Lestari, Aste Nunu Aa; Rusdiawan \& Sudirman. 2019. Kemampuan Guru Melaksanakan

Pembelajaran Bahasa Indonesia Berbasis Kurikulum 2013 di SMPN 1 Pujut Nusa Tenggara Barat.

Lingua (2019), 16(2): 207-218. Http://doi.org/10.30957/lingua.v16i2.268.

Indikator, tujuan pembelajaran, materi pembelajaran, metode pembelajaran, media, alat, sumber pembelajaran, langkah-langkah kegiatan pembelajaran (pendahuluan, kegiatan inti, dan penup), penilaian (jenis/teknik penilaian, bentuk instrumen dan instrumen, pedoman penskoran). Pada langkah-langkah pembelajaran yaitu pendahuluan, kegiatan inti, dan penutup dijabarkan lagi menjadi kegiatan pendahuluan meliputi komponen mengkondisikan siswa, apersepsi, motivasi dan menyampaikan tujuan pembelajaran. Kegiatan inti meliputi komponen mengamati, menanya, mengumpulkan data, mengasosiasikan, dan mengkomunikasikan. Kegiatan penutup meliputi komponen meninjau kembali, evaluasi, dan tindak lanjut.

Patut diingat bahwa desain pembelajaran yang umumnya disebut Rencana Pelaksanaan Pembelajaran (RPP) sudah memiliki format standar yang komponenkomponennya sudah relative baku. Oleh karena itu, dalam proses penelitian terhadap RPP tidak semua aspek yang ada didalamnya perlu untuk dielaborasi. Komponenkomponen RPP yang perlu dielaborasi adalah komponen yang membutuhkan pemikiran keras dari guru saat menyusunnya, komponen yang dimaksud diantaranya:

1. kemampuan mengembangkan indicator dari komponen dasar,

2. kemampuan meracik materi pembelajaran yang sesuai dengan indicator,

3. kemampuan menetapkan metode pembelajaran dalam bentuk langkah-langkah pembelajaran untuk menyajikan materi pembelajaran, termasuk di dalamnya menentukan jumlah pertemuan untuk menuntaskan pelaksanaan pembelajaran serta media pembelajaran yang digunakan

4. kemampuan menetapkan bentuk evaluasi capaian hasil pembelajaran

Komponen-komponen lain yang dalam RPP cenderung tidak membutuhkan kemampuan guru untuk mengelaborasi secara mendalam, tetapi dapat dikutip langsung dari kurikulum, seperti komponen kompetensi inti, kompetensi dasar, nama mata pelajaran, kelas, semester, dan lain-lain. Berbeda dengan keempat komponen di atas yang memang memerlukan pemikiran ekstra dari guru dalam mengisinya. Dengan demikian keempat poin di atas merupakan fokus yang memerlukan elaborasi pemikiran lanjutan untuk diteliti.

\section{METODE}

Jenis penelitian ini merupakan penelitian deskriptif dengan menggunakan pendekatan kualitatif. Penelitian ini menghasilkan data deskripsi berupa kata-kata tertulis atau lisan dari orang-orang dan prilaku yang dapat diamati. Hal ini berarti dalam penelitian ini data yang disajikan berupa kata-kata, kalimat-kalimat, atau teks yang bertujuan untuk memahami fakta dan fenomena yang terjadi pada subyek penelitian. Sasaran dalam penelitian ini adalah kegiatan pelaksanaan pembelajaran yang dilaksanankan oleh guru bahasa Indonesia di SMPN 1 Pujut Nusa Tenggara Barat pada jenjang kelas VII berdasarkan RPP yang dikembangkan oleh guru tersebut.

Metode yang digunakan dalam proses pengumpulan data yaitu metode simak (pengamatan atau observasi) dan metode cakap (wawancara). Metode simak digunakan untuk menyimak atau mengamati guru yang sedang mengimplementasikan atau 
mempraktikkan rancangan pembelajaran dalam proses kegiatan belajar mengajar di ruang kelas. Sedangkan metode cakap Metode Cakap merupakan metode yang pelaksanaannya dilakukan dengan cara peneliti melakukan percakapan atau kontak dengan subjek penelitian yaitu guru untuk mendapatkan informasi mengenai sejauh mana kemampuan atau pengetahuan guru mengenai RPP dan kurikulum yang sedang berlaku yaitu kurikulum 2013. Selanjutnya, metode yang digunakan dalam analisis data adalah metode Miles dan Huberman yang dilaksanakan dalam tiga langkah yaitu reduksi data (data reduction), penyajian data (data display), dan verifikasi (conclusion drawing).

\section{HASIL DAN PEMBAHASAN}

Penelitian ini membahas dua pokok persoalan yaitu menganalisis kesesuaian RPP yang disusun oleh guru bahasa Indonesia di SMPN 1 Pujut beserta kelengkapan komponen-komponen yang ada didalamnya. Berikut dipaparkan hasil analisis yan telah dilakukan.

\subsection{Kesesuaian RPP dengan Kurikulum 2013 dan Kelengkapan Komponen}

Penelitian ini difokuskan pada RPP yaitu RPP yang telah disusun oleh guru bahasa Indonesia kelas VII di SMPN 1 Pujut. RPP yang diambil sebagai objek penelitian adalah RPP yang membahas tentang materi teks fable. RPP yang sudah diperoleh oleh peneliti kemudian dianalisis kelengkapan komponen-komponen yang ada dalamnya.

\subsubsection{Rumusan Indikator RPP Bahasa Indonesia}

Indikator adalah tingkah laku operasional yang menjadi tanda tercapainya kompetensi dasar. Tingkah laku operasional artinya tingkah laku yang dapat diukur atau diamati (Priyatni, 44:2014). Jadi dapat dikatakan indicator adalah acuan dalam pengembangan rencana pelaksanaan pembelajaran agar tujuan pembelajaran yang hendak dicapai dapat terlaksana dengan baik dan tidak menyimpang. Pada tiga RPP yang telah diteliti ditemukan bahwa guru bahasa Indonesia di SMPN 1 Pujut telah mencantumkan indicator pada RPP yang telah mereka susun.

Hasil penelitian menunjukkan bahwa rumusan indikator pada RPP yang disusun oleh guru bahasa Indonesia di SMPN 1 Pujut masih kurang rinci dan rumusan indikator sebagian RPP menyalin apa adanya dari kompetensi dasar, sehingga rumusan indicator belum mampu mengukur kompetensi dasar serta kurang menggambarkan tahapan dalam pencapaian kompetensi.

\begin{tabular}{|l|l|}
\hline Kompetensi Dasar & Indikator \\
\hline $\begin{array}{l}\text { Kelas VII } \\
\text { Materi: Teks Fabel }\end{array}$ & $\begin{array}{c}3.12 .1 \text { Menjelaskan karakteristik bagian-bagian } \\
\text { struktur cerita fable }\end{array}$ \\
$\begin{array}{l}3.12 .2 \text { Mengidentifikasi struktur fabel } \\
\begin{array}{l}\text { legenda daerah struktur dan kebahasaan fabel/ } \\
\text { didengar. }\end{array}\end{array}$ & $\begin{array}{c}\text { Menyimpulkan prinsip penggunaan kata/ } \\
\text { kalimat pada cerita fabel }\end{array}$ \\
\hline
\end{tabular}


LINGUA, Vol. 16, No. 2, September 2019

p ISSN: 1979 9411; e ISSN: 2442 238X

Http://lingua.soloclcs.org; Email: presslingua@gmail.com

Center of Language and Cultural Studies, Surakarta, Indonesia

Lestari, Aste Nunu Aa; Rusdiawan \& Sudirman. 2019. Kemampuan Guru Melaksanakan

Pembelajaran Bahasa Indonesia Berbasis Kurikulum 2013 di SMPN 1 Pujut Nusa Tenggara Barat.

Lingua (2019), 16(2): 207-218. Http://doi.org/10.30957/lingua.v16i2.268.

Berdasarkan penjabaran RPP di atas dapat diketahui bahwa rumusan indikator telah sesuai dengan aspek rumusan indikator. Pada RPP tersebut hanya dicantumkan mengenai kompetensi dasar pada aspek pengetahuan saja. Berdasarkan wawancara dengan guru bahasa Indonesia kelas VII di SMPN 1 Pujut diketahui bahwa alasan guru tersebut hanya mencantumkan KD aspek pengetahuan adalah karena pada RPP tersebut difokuskan untuk memberikan pengetahuan siswa mengenai struktur, isi, dan fitur bahasa teks fable. Aspek keterampilan akan difokuskan pada RPP yang berbeda. Selain itu, guru mata pelajaran tidak menyertakan KD untuk aspek spiritual dan aspek sosial. Hal tersebut disebabkan guru memahami bahwa aspek spiritual dan aspek sosial pada KD 1 dan KD 2 merupakan pembelajaran tidak langsung.Oleh karena itu indikator dan tujuan pembelajarannya terintegrasi pada KD 3 yaitu aspek pengetahuan dan KD 4 yaitu aspek keterampilan. Pembelajaran tidak langsung adalah proses pendidikan yang terjadi selama proses pembelajaran langsung tetapi tidak dirancang dalam kegiatan khusus. Pembelajaran tidak langsung berkenaan dengan pengembangan nilai dan sikap (Permendikbud Nomor 81A Tahun 2013 tentang Implementasi Kurikulum).

Berdasarkan tabel di atas, dapat diketahui bahwa rumusan indikator telah sesuai dengan kompetensi dasar pada aspek pengetahuan. Rumusan indikator yang telahdisusun oleh guru bahasa Indonesia di SMPN1 Pujut juga dapat dikatakan telah menunjang pencapaian kompetensi dan tidak menimbulkan penafsiran ganda. Ini tampak dari indikator yang telah terinci dengan baik.

\subsubsection{Perumusan Tujuan Pembelajaran RPP Bahasa Indonesia}

Tujuan pembelajaran merupakan salah satu dari beberapa komponen penting yang harus ada pada sebuah RPP. Tujuan pembelajaran yang dirumuskan guru dalam RPP harus sesuai dengan kompetensi dasar yang dikembangkan melalu aspek sikap, aspek pengetahuan, dan aspek keterampilan. RPP yang disusun oleh guru bahasa Indonesia di SMPN1 Pujut tidak mencantumkan tujuan pembelajran. Subjek penelitian yaitu guru bahasa Indonesia di SMPN 1 Pujut beralasan bahwa tujuan pembelajaran sudah terlihat pada rumusan indicator, oleh sebab itu tujuan pembelajaran tidak dimunculkan dalam RPP yang telah ia susun.

Indikator pembelajaran dan tujuan pembelajaran merupakan dua komponen RPP yang sangat penting. Kedua komponen tersebut menetukan kemana arah dari pembelajaran akan dijalankan. Oleh karena itu, kedua komponen tersebut harus hadir dalam RPP.

\subsubsection{Pengembangan Materi Pembelajaran RPP Bahasa Indonesia}

Mulyasa (2007:225) menjelaskan bahwa materi pembelajaran adalah bahan pembelajaran berkenaan dengan sesuatu yang harus dipelajari oleh peserta didik untuk memperoleh kompetensi.Hal-hal yang harus diperhatikan ketika menyusun materi pembelajaran adalah sebagai berikut:

1. Materi memuat fakta, konsep, prinsip, dan prosedur yang relevan.

2. Materi pembelajaran ditulis dalam bentuk butir-butir sesuai dengan rumusan indicator ketercapaian kompetensi (Priyatni, 2014:172) 
LINGUA, Vol. 16, No. 2, September 2019

p ISSN: 1979 9411; e ISSN: 2442 238X

Http://lingua.soloclcs.org; Email: presslingua@gmail.com

Center of Language and Cultural Studies, Surakarta, Indonesia

Lestari, Aste Nunu Aa; Rusdiawan \& Sudirman. 2019. Kemampuan Guru Melaksanakan

Pembelajaran Bahasa Indonesia Berbasis Kurikulum 2013 di SMPN 1 Pujut Nusa Tenggara Barat.

Lingua (2019), 16(2): 207-218. Http://doi.org/10.30957/lingua.v16i2.268.

Pada aspek pengembangan materi, RPP yang telah disusun oleh guru bahasa Indonesia di SMPN 1 Pujut sudah mencantumkan materi yang telah mengacu pada indikator pembelajaran dan dapat digunakan untuk mencapai kompetensi dasar. Namun dalam proses observasi lebih mendalam diketahui bahwa guru bahasa Indonesia di SMPN 1 Pujut hanya mencantumkan pokok-pokok materi saja tanpa dilampirkan penjelasan tentang materi pembelajaran.

\subsubsection{Perencanaan Metode Pembelajaran RPP Bahasa Indonesia}

Metode belajar adalah cara untuk melakukan aktivitas yang tersistem dari sebuah lingkungan yang terdiri dari gurudan peserta didik untuk saling berinteraksi dalam melakukan suatu kegiatan sehingga proses belajar berjalan dengan baik dan tujuan dari proses pembelajaran dapat tercapai sesuai dengan yang telah dirumuskan oleh guru. Hal ini berarti metode pembellajaran digunakan untuk merealisasikan strategi pembelajaran yang telah disusun (Mudlofir, 2017:105).

Berdasarkan hasil penelitian gurubahasa Indonesia di SMPN 1 Pujut tidak mencantumkan metode pembelajaran yang akan digunakan dalam proses belajar mengajar. Dalam RPP yang telah disusunnya, subjek penelitian hanya mencantumkan pendekatan yang digunakan yaitu pendekatan saintifik. Hal ini dilakukan oleh subjek penelitian dengan alasan bahwa metode pembelajaran bersifat situasional yaitu dipilih dan dilaksanakan sesuai dengan situasi dan kondisi kelas saat itu. Seharusnya, setiap RPP wajib mencantumkan metode pembelajaran yang menjadi panduan guru dalam melaksanakan kegiatan pembelajaran agar tercipta suasana belajar dan proses pembelajaran yang sesuai dengan karakteristik peserta didik dan KD yang akan dicapai.

\subsubsection{Pemilihan Media dan Sumber Belajar RPP Bahasa Indonesia}

Sumber belajar adalah alat atau barang yang bisa dimanfaatkan untuk menunjang proses belajar mengajar baik secara langsung maupun tidak langsung, sebagian atau secara keseluruhan (Mudlofir, 2017:193). Sumber belajar dalam proses belajar mengajar harus digunakan sebagai inspirasi dan sumber belajar bagi peserta didik dan guru dalam memperoleh pengetahuan dan mendapatkan proses pembelajaran secara bermakna yang akan memberikan bekal bagi kehidupannya di masyarakat. Sedangkan Media pembelajaran adalah segala jenis sarana pendidikan yang digunakan sebagai perantara dalam proses belajar mengajar untuk meningkatkan efektivitas dan efisiensi pencapaian tujuan instruksional. Mencangkup media grafis, media yang menggunakan alat penampil, peta, model, globe, dan sebagainya (Rohani dalam Mudlofir, 2017:123). Media belajar berfungsi untuk mendorong motivasi belajar, memperjelas dan mempermudah konsep yang abstrak dan mempertinggi daya serap atau retensi belajar.

Pemilihan sumber belajar dan media pembelajaran telah sesuai dengan indicator. Dalam merumuskan sumber dan media pembelajaran guru hanya mencantumkan sumber belajar dan media pembelajaran, sedangkan ketersediaan wujud sumber belajar dan media pembelajaran tidak dilampirkan pada RPP. 
LINGUA, Vol. 16, No. 2, September 2019

p ISSN: 1979 9411; e ISSN: 2442 238X

Http://lingua.soloclcs.org; Email: presslingua@gmail.com

Center of Language and Cultural Studies, Surakarta, Indonesia

Lestari, Aste Nunu Aa; Rusdiawan \& Sudirman. 2019. Kemampuan Guru Melaksanakan

Pembelajaran Bahasa Indonesia Berbasis Kurikulum 2013 di SMPN 1 Pujut Nusa Tenggara Barat.

Lingua (2019), 16(2): 207-218. Http://doi.org/10.30957/lingua.v16i2.268.

\subsubsection{Perencanaan Langkah Pembelajaran RPP Bahasa Indonesia}

Permendikbud No. 81A tentang Implementasi Kurikulum 2013 dijelaskan bahwa RPP paling sedikit memuat identitas sekolah (sekolah, matapelajaran, Kelas/semester, materi pokok, alokasi waktu), Kompetensi Inti, Kompetensi Dasar dan Indikator, tujuan pembelajaran, materi pembelajaran, metode pembelajaran, media, alat, sumber pembelajaran, langkah-langkah kegiatan pembelajaran (pendahuluan, kegiatan inti, dan penup), penilaian (jenis/teknik penilaian, bentuk instrumen dan instrumen, pedoman penskoran). Pada langkah-langkah pembelajaran yaitu pendahuluan, kegiatan inti, dan penutup dijabarkan lagi menjadi kegiatan pendahuluan meliputi komponen mengkondisikan siswa, apersepsi, motivasi dan menyampaikan tujuan pembelajaran. Kegiatan inti meliputi komponen mengamati, menanya, mengumpulkan data, mengasosiasikan, dan mengkomunikasikan. Kegiatan penutup meliputi komponen meninjau kembali, evaluasi, dan tindak lanjut.

Permendikbud No. 81A tentang Implementasi Kurikulum 2013 perencanaan langkah-langkah pembelajaran secara umum mencakup kegiatan pendahuluan, kegiatan inti, dan kegiatan penutup dengan beberapa langkah yang harus dilakukan disetiap kegiatan tersebut. Berdasarkan hasil penelitian, RPP yang telah disusun oleh guru bahasa Indonesia di SMPN 1 Pujut telah mencantumkan langkah-langkah pembelajaran yang terdiri dari kegiatan pendahuluan, kegiatan inti, dan kegiatan penutup. Kegiatan pendahuluan telah mencakup aspek menyampaian tujuan pembelajaran/menyampaikan apersepsi awal tentang materi yang akan dipelajari, tetapi subjek penelitian tidak memaparkan aspek mengaitkan kehidupan nyata dan pengetahuan terdahulu dengan KD pada RPP yang telah disusun. Pada kegiatan inti, langkah-langkah pembelajaran telah tersusun dengan lengkap. Pada kegiatan penutup, guru masih belum memaparkan mengenai arahan tindak lanjut pembelajaran pada RPP yang telah mereka susun.

\subsubsection{Perencanaan Penilaian RPP Bahasa Indonesia}

Proses penilaian merupakan salah satu dari empat tugas pokok guru sebagai pengajar. Penilaian adalah suatu kegiatan untuk memberikan berbagai informasi secara berkesinambungan dan menyeluruh tentang proses dan hasil yang telah dicapai siswa (Depdikbud dalam Arifin, 4:2014). Penilaian pada kurikulum 2013 menggunakan penilaian autentik. Penilaian autentik disini maksudnya penilaian yang penilaian yang dilakukan secara komprehensif untuk menilai mulai dari masukan (input), proses, dan keluaran (output) pembelajaran, yang meliputi ranah sikap, pengetahuan, dan keterampilan.

Berdasarkan hasil pengamatan terhadap RR yang telah disusun oleh guru bahasa Indonesia di SMPN 1 Pujut diketahui bahwa subjek penelitian hanya menyusun perencanan penilaian untuk aspek pengetahuan saja.Hal ini tidak sesuai dengan Permendikbud Nomor 66 Tahun 2013 tentang Standar Penilaian yang menyatakan bahwa penilaian hasil belajar peserta didik mencakup kompetensi sikap, pengetahuan, dan keterampilan yang dilakukan secara berimbang sehingga dapat digunakan untuk menentukan posisi relatif setiap peserta didik terhadap standar yang telah ditetapkan. 
LINGUA, Vol. 16, No. 2, September 2019

p ISSN: 1979 9411; e ISSN: 2442 238X

Http://lingua.soloclcs.org; Email: presslingua@gmail.com

Center of Language and Cultural Studies, Surakarta, Indonesia

Lestari, Aste Nunu Aa; Rusdiawan \& Sudirman. 2019. Kemampuan Guru Melaksanakan

Pembelajaran Bahasa Indonesia Berbasis Kurikulum 2013 di SMPN 1 Pujut Nusa Tenggara Barat.

Lingua (2019), 16(2): 207-218. Http://doi.org/10.30957/lingua.v16i2.268.

Pada perencanaan penilaian untuk aspek pengetahuan tersebut telah dilengkapi instrumen yang sesuai dengan indikator namun belum dicantumkan bentuk dan teknik penilaian. RPP yang disusun oleh guru bahasa Indonesia di SMPN 1 Pujut pada aspek perencanaan penilaian hanya mencakup beberapa dari seluruh indikator dan tersusun tanpa kriteria penilaian. RPP tersebut hanya mencantumkan beberapa pertanyaan tanpa dilengkapi dengan kriteria penilaian. Penilaian seharusnya dilakukan dengan menilai semua indikator yang tercantum dalam kompetensi dasar bukan hanya pada beberapa indicator saja. Setiap indikator yang telah disusun harus diukur dengan alat ukur yang jelas. Akan tetapi, pada RPP yang telah disusun oleh guru SMPN 1 Pujut perencanaan penilaian tidak mencakup seluruh indicator. Berdasarkan hasil penelitian maka diketahui kesesuaian RPP yang disusun oleh guru bahasa Indonesia di SMPN 1 Pujut dengan Kurikulum 2013 serta kelengkapan komponen yang ada di dalamnya bisa dikatakan belum sesuai karena ada beberapa komponen dari RPP yang tidak dicantumkan.

\subsection{Analisis Kesesuaian Proses Pembelajaran dengan RPP yang dibuat Guru}

Analisis kesesuaian RPP dengan proses pembelajaran didasarkan pada kesesuain RPP yang telah disusun oleh guru bahasa Indonesia di SMPN 1 Pujut dengan pembelajaran yang dilakukan oleh guru yang bersangkutan di kelas. Berikut dipaparkan presentase kesesuaian RPP yang dibuat oleh guru dengan proses pembelajaran di kelas.

Tabel 1. Persentase Penilaian Proses Pelaksanaan Pembelajaran Guru Bahasa Indonesia SMPN 1 Pujut dengan RPP yang Dikembangkan oleh Guru

\begin{tabular}{|c|c|c|}
\hline \multicolumn{2}{|r|}{ Aspek yang Diamati } & RPP \\
\hline \multicolumn{3}{|c|}{ Kegiatan Pendahuluan } \\
\hline \multicolumn{3}{|c|}{ Apersepsi dan Motivasi } \\
\hline 1 & $\begin{array}{l}\text { Menyiapkan fisik dan psikis peserta didik dengan menyapa dan memberi } \\
\text { salam }\end{array}$ & $\sqrt{ }$ \\
\hline 2 & $\begin{array}{l}\text { Mengajukan pertanyaan-pertanyaan tentang materi yang sudah dipelajari dan } \\
\text { terkait dengan materi yang akan dipelajari }\end{array}$ & - \\
\hline 3 & Menjelaskan tujuan pembelajaran atau KD yang akan dicapai & - \\
\hline 4 & $\begin{array}{l}\text { menyampaikan garis besar cakupan materi dan penjelasan tentang kegiatan } \\
\text { yang akan dilakukan peserta didik }\end{array}$ & $\sqrt{ }$ \\
\hline \multicolumn{3}{|c|}{ Kegiatan Inti } \\
\hline \multicolumn{3}{|c|}{ Penguasaan materi pembelajaran } \\
\hline 1 & Kemampuan menyesuaikan materi dengan tujuan pembelajaran. & - \\
\hline 2 & $\begin{array}{l}\text { Kemampuan mengkaitkan materi dengan pengetahuan lain yang relevan, } \\
\text { perkembangan Iptek, dan kehidupan nyata. }\end{array}$ & - \\
\hline 3 & Menyajikan pembahasan materi pembelajaran dengan tepat. & $\sqrt{ }$ \\
\hline 4 & Menyajikan materi secara sistematis (mudah ke sulit, dari konkrit ke abstrak) & $\sqrt{ }$ \\
\hline \multicolumn{3}{|c|}{ Penerapan strategi pembelajaran yang mendidik } \\
\hline 1 & Melaksanakan pembelajaran sesuai dengan kompetensi yang akan dicapai & $\sqrt{ }$ \\
\hline 2 & Melaksanakan pembelajaran secara runtut & $\sqrt{ }$ \\
\hline
\end{tabular}


LINGUA, Vol. 16, No. 2, September 2019

p ISSN: 1979 9411; e ISSN: 2442 238X

Http://lingua.soloclcs.org; Email: presslingua@gmail.com

Center of Language and Cultural Studies, Surakarta, Indonesia

Lestari, Aste Nunu Aa; Rusdiawan \& Sudirman. 2019. Kemampuan Guru Melaksanakan

Pembelajaran Bahasa Indonesia Berbasis Kurikulum 2013 di SMPN 1 Pujut Nusa Tenggara Barat.

Lingua (2019), 16(2): 207-218. Http://doi.org/10.30957/lingua.v16i2.268.

\begin{tabular}{|c|c|c|}
\hline \multicolumn{2}{|r|}{ Aspek yang Diamati } & \multirow[t]{2}{*}{ RPP } \\
\hline 3 & Menguasai kelas & \\
\hline 4 & $\begin{array}{l}\text { Melaksanakan pembelajaran yang menumbuhkan partisipasi aktif peserta } \\
\text { didik dalam mengajukan pertanyaan }\end{array}$ & - \\
\hline 5 & $\begin{array}{l}\text { Melaksanakan pembelajaran yang menumbuhkan partisipasi aktif peserta } \\
\text { didik dalam mengemukakan pendapat }\end{array}$ & - \\
\hline 6 & $\begin{array}{l}\text { Melaksanakan pembelajaran yang mengembangkan ketrampilan peserta didik } \\
\text { sesuai dengan materi ajar }\end{array}$ & $\sqrt{ }$ \\
\hline 7 & Melaksanakan pembelajaran yang bersifat kontekstual & - \\
\hline 8 & $\begin{array}{l}\text { Melaksanakan pembelajaran yang memungkinkan tumbuhnya kebiasaan dan } \\
\text { sikap positif (nurturant effect) }\end{array}$ & - \\
\hline 9 & Melaksanakan pembelajaran sesuai dengan alokasi waktu yang direncanakan & $\sqrt{ }$ \\
\hline \multicolumn{3}{|c|}{ Penerapan Pendekatan Scientific } \\
\hline 1 & Memfasilitasi dan menyajikan kegiatan bagi peserta didik untuk mengamati & $\sqrt{ }$ \\
\hline 2 & Memancing peserta didik untuk bertanyaapa, mengapa dan bagaimana & - \\
\hline 3 & $\begin{array}{l}\begin{array}{l}\text { menfasilitasi dan menyajikan kegiatan bagi peserta didik untuk } \\
\text { mengumpulkan informasi }\end{array} \\
\end{array}$ & $\sqrt{ }$ \\
\hline 4 & $\begin{array}{l}\text { Memfasilitasi dan menyajikan kegiatan bagi peserta didik untuk } \\
\text { mengasosiasikan data dan informasi yang dikumpulkan }\end{array}$ & $\sqrt{ }$ \\
\hline 5 & $\begin{array}{l}\text { Menfasilitasi dan menyajikan kegiatan bagi peserta didik } \\
\text { mengkomunikasikan pengetahuan dan ketrampilan yang diperolehnya }\end{array}$ & $\sqrt{ }$ \\
\hline \multicolumn{3}{|c|}{ Pemanfaatan sumber belajar/media dalam pembelajaran } \\
\hline 1 & $\begin{array}{l}\begin{array}{l}\text { Menunjukkan keterampilan dalam penggunaan sumber belajar } \\
\text { bervariasi }\end{array} \\
\end{array}$ & - \\
\hline 2 & Menunjukkan keterampilan dalam penggunaan media pembelajaran & - \\
\hline 3 & Melibatkan peserta didik dalam pemanfaatan sumber belajar pembelajaran & $\sqrt{1}$ \\
\hline 4 & Melibatkan peserta didik dalam pemanfaatan media pembelajaran & - \\
\hline 5 & Menghasilkan pesan yang menarik & - \\
\hline \multicolumn{3}{|c|}{ Pelaksanaan Penilaian Autentik } \\
\hline 1 & Melaksanakan Penilaian Sikap & $\sqrt{ }$ \\
\hline 2 & Melaksanakan Penilaian Pengetahuan & $\sqrt{ }$ \\
\hline 3 & Melaksanakan Penilaian Ketrampilan & $\sqrt{ }$ \\
\hline 4 & Kesesuaian tehnik dan instrumen dengan indikator pencapaian kompetensi & $\sqrt{ }$ \\
\hline 5 & Kesesuaian antara bentuk, tehnik dan instrumen penilaian autentik. & $\sqrt{1}$ \\
\hline 6 & Ketersediaan pedoman penskoran & - \\
\hline \multicolumn{3}{|c|}{ Pelibatan peserta didik dalam pembelajaran } \\
\hline 1 & $\begin{array}{l}\text { Menumbuhkan partisipasi aktif peserta didik melalui interaksi guru, peserta } \\
\text { didik, sumber belajar }\end{array}$ & - \\
\hline
\end{tabular}


LINGUA, Vol. 16, No. 2, September 2019

p ISSN: 1979 9411; e ISSN: 2442 238X

Http://lingua.soloclcs.org; Email: presslingua@gmail.com

Center of Language and Cultural Studies, Surakarta, Indonesia

Lestari, Aste Nunu Aa; Rusdiawan \& Sudirman. 2019. Kemampuan Guru Melaksanakan

Pembelajaran Bahasa Indonesia Berbasis Kurikulum 2013 di SMPN 1 Pujut Nusa Tenggara Barat.

Lingua (2019), 16(2): 207-218. Http://doi.org/10.30957/lingua.v16i2.268.

\begin{tabular}{|c|c|c|}
\hline \multicolumn{2}{|r|}{ Aspek yang Diamati } & RPP \\
\hline 2 & Merespon positif partisipasi peserta didik & $\sqrt{ }$ \\
\hline 3 & Menunjukkan sikap terbuka terhadap respons peserta didik & $\sqrt{ }$ \\
\hline 4 & Menunjukkan hubungan antar pribadi yang kondusif & $\sqrt{ }$ \\
\hline 5 & Menumbuhkan keceriaan atau antusiasme peserta didik dalam belajar & - \\
\hline \multicolumn{3}{|c|}{ Penggunaan bahasa yang benar dan tepat dalam pembelajaran } \\
\hline 1 & Menggunakan bahasa lisan secara jelas dan lancar & $\sqrt{ }$ \\
\hline 2 & Menggunakan bahasa tulis yang baik dan benar & $\sqrt{ }$ \\
\hline \multicolumn{3}{|c|}{ Kegiatan Penutup } \\
\hline \multicolumn{3}{|c|}{ Penutup pembelajaran } \\
\hline 1 & $\begin{array}{l}\text { Menfasilitasi dan membimbing peserta didik untuk merangkum materi } \\
\text { pelajaran }\end{array}$ & $\sqrt{ }$ \\
\hline 2 & $\begin{array}{l}\text { Menfasilitasi dan membimbing peserta didik untuk merefleksi proses dan } \\
\text { materi pelajaran }\end{array}$ & - \\
\hline 3 & Memberikan tes lisan atau tulisan & $\sqrt{ }$ \\
\hline 4 & memberikan umpan balik terhadap proses dan hasil pembelajaran & - \\
\hline 5 & $\begin{array}{l}\text { merencanakan kegiatan tindak lanjut dalam bentuk pembelajaran remedi, } \\
\text { program pengayaan, layanan konseling dan/atau memberikan tugas baik tugas } \\
\text { individual maupun kelompok sesuai dengan hasil belajar peserta didik }\end{array}$ & - \\
\hline 6 & menyampaikan rencana pembelajaran pada pertemuan berikutnya & - \\
\hline \multicolumn{2}{|r|}{ Jumlah } & 26 \\
\hline \multicolumn{2}{|r|}{ Presentase } & $54.34 \%$ \\
\hline
\end{tabular}

Tabel diadaptasi dari modul "Materi Pelatihan Implementasi Kurikulum 2013 Tahun Ajaran 2014/2015

Mata Pelajaran Bahasa Indonesia SMP”

Berdasarkan Tabel 1 persentase kesesuaian proses pembelajaran dengan RPP yang disusun oleh guru bahasa Indonesia di SMPN 1 Pujut memiliki presentase sebesar $54.34 \%$ dengan kriteria kurang sesuai. Hal tersebut disebabkan guru bahasa Indonesia di SMPN 1 Pujut dalam proses pembelajaran tidak menggunakan media pembelajaran sesuai dengan RPP yang sudah dikembangkan serta ada beberapa komponen dalam RPP yang tidak diterapkan dalam kegiatan belajar mengajar di kelas. Berdasarkan angket penilaian diri guru, hal ini disebabkan karena media yang tidak selalu ada di sekolah, penilaian yeng terlalu banyak, jumlah siswa yang terlalu banyak serta kondisi kelas yang menyebabkan rencana pembelajaran yang telahtersusun sulit untuk diterapkan secara sempurna.

Dari analisis data mengenai pembelajaran bahasa Indonesia berdasarkan pendekatan Kurikulum 2013 di SMPN 1 Pujut menunjukkan bahwa penerapan pendekatan saintifik terlihat dalam langkah-langkah pembelajaran. Pada tahap pelaksanaan pembelajaran, guru menerapkan pendekatan saintifik dalam langkahlangkah pembelajaran, khususnya dalam kegiatan inti pembelajaran walaupun 
LINGUA, Vol. 16, No. 2, September 2019

p ISSN: 1979 9411; e ISSN: 2442 238X

Http://lingua.soloclcs.org; Email: presslingua@gmail.com

Center of Language and Cultural Studies, Surakarta, Indonesia

Lestari, Aste Nunu Aa; Rusdiawan \& Sudirman. 2019. Kemampuan Guru Melaksanakan

Pembelajaran Bahasa Indonesia Berbasis Kurikulum 2013 di SMPN 1 Pujut Nusa Tenggara Barat.

Lingua (2019), 16(2): 207-218. Http://doi.org/10.30957/lingua.v16i2.268.

pelaksanaannya belum sempurna. Kegiatan pokok dalam pendekatan saintifik yaitu mengamati, menanya, mencoba, mengasosiasi, dan mengomunikasikan. Kegiatankegiatan tersebut tidak dapat terlaksana seluruhnya terutama kegiatan menanya dan mengkomunikasikan karena terkendala waktu, kemampuan siswa dalam menyerap materi pembelajaran yang tidak merata, serta kondisi siswa yang lebih banyak diam atau tidak berpartisipasi aktif dalam kegiatan belajar mengajar. Kegiatan penutup yang dilaksanakan tidak sesuai dengan RPP. Guru hanya memberikan tugas sebagai acuan untuk mengetahui sejauhmana pemahaman siswa mengenai materi yang diberikan.

Jadi, bisa dikatakan bahwa guru memiliki beberapa kendala dalam menerapkan pembelajaran bahasa Indonesia berdasarkan pendekatan saintifik berbasis kurikulum 2013. Kendala-kendala yang dimaksud adalah ketidaksesuaian antara waktu yang tersedia dengan cakupan materi pembelajaran yang terlalu luas, kondisi kelas serta kemampuan siswa dalam menyerap dan memahami materi sangat kurang .

\section{SIMPULAN}

Berdasarkan penelitian yang telah dilakukan dapat disimpulkan bahwa kesesuaian RPP yang disusun oleh guru bahasa Indonesia di SMPN 1 Pujut dengan Kurikulum 2013 serta kelengkapan komponen yang ada di dalamnya bisa dikatakan belum sesuai karena ada beberapa komponen dari RPP yang tidak dicantumkan. Selanjutnya dilihat dari kesesuaian proses pembelajaran guru bahasa Indonesia kelas VIIdi SMP Negeri 1 Pujut dengan RPP yang telah disusun dikategorikan kurang sesuai, dengan presentase sebesar 54.34\%. Berdasarkan hasil analisis maka perlu dilakukan kembali pelatihan mengenai Kurikulum 2013 secara merata dengan pendampingan yang dilakukan dengan lebih intensif.

DAFTAR PUSTAKA

Arifin, Zainal. (2014). Evaluasi Pebelajaran: Prinsip Teknin Prosedur. Bandung: Remaja Rosdakarya

Bariyah, Lailatul. 2014. Analisis Kesesuaian RPP dan Pelaksanaan Pembelajaran Guru SMPN di Kabupaten Mojokerto pada Sub Materi Fotosintesis dengan Kerikulum 2013. Jurnal BioEdu, Vol 03, hlm 453-460.

Bintari, Ni Luh Gede Riwan Putri. 2014. Pembelajaran Bahasa Indonesia BerdasarkanPendekatan Saintifik (Problem Based Learning) Sesuai Kurikulum 2013 di Kelas VIISMP Negeri 2 Amlapura. E-Journal Program Pascasarjana Universitas Pendidikan Ganesha Program Studi Pendidikan Bahasa Indonesia, vol 03

Daryanto dan Dwicahyono, Aris. (2014). Pengembangan Perangkat Pembelajaran: Silabus, RPP, PHB, Bahan Ajar. Yogyakarta: Gava Media

Kementrian Pendidikan dan Kebudayaan. (2014). Materi Pelatihan Implementasi 2013 Tahun Ajaran 2014/2015 Mata Pelajaran Bahasa Indonesia SMP: Badan Pengembangan Sumber Daya Manusia Pendidikan dan Kebudayaan dan Penjaminan Mutu Pendidikan Kementerian Pendidikan dan Kebudayaan 
LINGUA, Vol. 16, No. 2, September 2019

p ISSN: 1979 9411; e ISSN: 2442 238X

Http://lingua.soloclcs.org; Email: presslingua@gmail.com

Center of Language and Cultural Studies, Surakarta, Indonesia

Lestari, Aste Nunu Aa; Rusdiawan \& Sudirman. 2019. Kemampuan Guru Melaksanakan

Pembelajaran Bahasa Indonesia Berbasis Kurikulum 2013 di SMPN 1 Pujut Nusa Tenggara Barat.

Lingua (2019), 16(2): 207-218. Http://doi.org/10.30957/lingua.v16i2.268.

Mahayoningrum, Prita. (2014). Analisis Rencana Pelaksanaan Pembelajaran (RPP)

Bahasa Indonesia Aspek Keterampilan Menulis Kelas XI SMA Negeri 2 Jember

Tahun Ajaran 2012/2013 : Universitas Jember

Mahsun. (2014). Teks dalam Pembelajaran Bahasa Indonesia Kurikulum 2013. Jakarta:

Raja Grafindo Persada

Martiyono, dkk. (2014). Mengelola dan Mendampingi Implementasi Kurikulum 2013:

Adaptasi Hasil Pelatihan Kepala Sekolah, Guru Mata Pelajaran, dan Pendamping. Yogyakarta: Aswaja Pressindo

Mudlofir, Ali dan Rusydiyah, Evi Fatimatur.(2017). Desain Pembelajaran Inovatif: Dari Teori ke Praktik. Jakarta: Rajawali Pers

Mulyasa, E. (2007). Kurikulum Tingkat Satuan Pendidikan: Suatu Panduan Praktis. Bandung: Remaja Rosdakarya.

Muhammad. (2014). Metode Penelitian Bahasa.Jogjakarta: Ar-Ruzz Media

Peraturan Menteri Pendidikan dan Kebudayaan Nomor 81A Tahun 2013 tentang Implementasi Kurikulum 2013.

Peraturan Menteri Pendidikan dan Kebudayaan No. 64, Standar Isi Pendidikan Dasar dan Menengah.

Peraturan Pemerintah RI Nomor 32 Tahun 2013, Perubahan atas Peraturan Pemerintah Nomor 19 Tahun 2005 tentang Standar Nasional Pendidikan.

Priyatni, Endah Tri. (2014). Desain Pembelajaran Bahasa Indonesia Dalam Kurikulum 2013. Jakarta: Bumi Aksara

Setyawanto, Agung. Rencana Pelaksanaan Pembelajaran (RPP) Guru Bahasa IndonesiaTingkat SMP di Kota Malang. Malang: Universitas Negeri Malang

Sugiyono. (2018). Metode Penelitian Pendidikan: Pendekatan Kuantitatif, Kualitatif, dan $R \& D$. Bandung: Alfabeta

Suhertuti. (2017). Persepsi Guru Bahasa Indonesia Terhadap Materi Sastra pada Kurikulum Tingkat Satuan Pendidikan dan Kurikulum 2013.1(2).170188.doi.org/10.21009/AKSIS.271217

Syamsuddin dan Damaianti, Vismaia S. (2011). Metode Penelitian Pendidikan Bahasa. Bandung: Remaja Rosdakarya

Tim Dosen Administrasi Pendidikan Universitas Pendidikan Indonesia. 2009. Manajemen Pendidikan. Bandung: Alfabeta

Undang-undang Republik Indonesia No. 20 Tahun 2003, Sistem Pendidikan Nasional. 